\title{
Obituary
}

\section{John Conrad Waterlow CMG, FRS, FRCP, DSc}

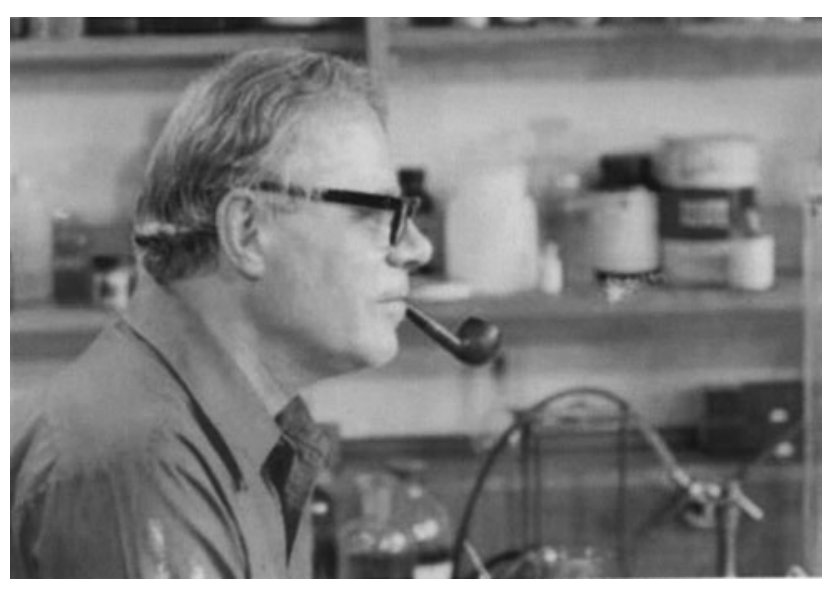

John Conrad Waterlow died on 19 October 2010. His passing brought an end to a life characterised by service to people, some of whom he would meet and care for and millions of whom he would never see, but who would benefit from what he did, who he was and what he left behind. There was service to the hard mistress of science, service to the Caribbean and service to the University of the West Indies to which he was passionately committed and which he would call his home for much of his scientific life. There was service in nurturing those fortunate men and women who became his scientific children and whose contributions to science and society he often regarded as his greatest service of all.

It is not strange that service should be the axle of the wheel of his life. He came from a line of servants and was schooled into a tradition of service. His father was ambassador to Siam, Abyssinia, Bulgaria and Greece; his grandfather was Mayor of London. Ambassadors are usually ministers of the highest rank and are critical functionaries in modern politics. Before the advent of modern communications and the age of instant interconnectedness, they were even more important, but in spite of the trappings of office, we should recall that the word ambassador is derived from the Latin ambactus, which means servant and service is indeed their pristine role. John Waterlow was one of the finest ambassadors to the Caribbean from Britain in the truest sense of the word. His milieu was the laboratory bench and not the formal diplomatic salons, his garb was the laboratory coat and not the pinstripe grey, and the credentials he presented were to the harsh court of scientific peers and not to any head of state. His legacy was not one of wars avoided or trade negotiations concluded, but the tremendous scientific production of one of the world's pre-eminent nutritional scientists and a line of disciples, many of whom have also devoted their lives to service of one kind or another. There are many facets to the life of John Waterlow, but here we chronicle what this ambassador, this scientific father of many, this mighty 'fisher' of men and women meant to the Caribbean and to the University of the West Indies.

John had a brilliant academic career and showed qualities of leadership from an early age. He was schooled at Eton, where he was taught Latin, Greek and Divinity and became captain of the School. It was never clear how much of the last stuck to him, but he retained an abiding affection for the classics, and his writings showed many a turn of phrase that was classical in construction. He went up to Cambridge on a scholarship in the classics, but changed to medicine, did brilliantly and even thought of becoming a professional physiologist, but eventually qualified in medicine during the Second World War. He would tell of anaesthetising critically wounded patients for urgent surgical procedures during the blitz with diethyl ether or chloroform, using simply a rag and bottle. At the end of the war, he joined a Human Nutrition Institute under Professor Platt whose prescient advice was that nutrition would be the problem of the future and who, in 1945, sent him to the Caribbean on behalf of the Colonial Office to find out why so many infants and young children were dying. John's account of his year in the Caribbean, visiting British Guiana, Trinidad and Jamaica, makes fascinating reading. He describes being sent to the far north of British Guiana to the Pakaraima Mountains to look at the health of the Akowoio Indians, and on completion of his mission being offered the post of Director of Aboriginal Medical Services by the Governor. He declined and noted that one of the reasons was that he knew so little about obstetrics and gynaecology, an ignorance that stuck in his mind as he tried to carry out a vaginal examination on an aboriginal lady lying in a hammock! A meeting in 1946 with the members of the Irvine Commission sent out from Britain to examine the possibility of University education in the Caribbean made a great impression on him, and he decided then that he wished to be a part of any university initiative in the West Indies. He returned to Britain after a year and wandered far and wide 
over land and sea, investigating various nutritional problems. But the call of the Caribbean was irresistible, so he then returned to the University College of the West Indies in 1950 to teach physiology, carry out research on childhood malnutrition and eventually establish the Tropical Metabolism Research Unit (TMRU) in 1954 - a unit that has aptly been described as the house that John built. He chose the name deliberately. He wished the Unit to be engaged in the study of the metabolic perturbations and controls that were found in the diseases in the tropics. He sometimes contended that the appellation tropical was simply to indicate the geographical locus, but it was always his view that although Caribbean science was primarily science in and of the Caribbean, there was an indivisibility of science, which meant that findings there would have applicability elsewhere. He eschewed the false division of science into what was basic and what was applied and would often quip that the only two divisions were into good science and bad science.

John did not only set the example of doing good science, but as the first Secretary of the Standing Advisory Committee for Medical Research in the British Caribbean, he would lay the foundations of the current Caribbean Health Research Council, still dedicated to showcasing the best of Caribbean science and providing a forum for young scientists to show their wares. John was a nutritional scientist, and the several path-breaking discoveries to his name are essentially in that field. He investigated thoroughly the fatty liver of children with kwashiorkor and would make a significant contribution to the clinical classification of childhood malnutrition. His measurements of metabolic reactions in tiny pieces of liver tissue with a microrespirometer were a source of amazement to his peers. However, John would undoubtedly agree that his major contribution to nutrition in general was his work on protein turnover - the breakdown and synthesis of protein. Even to the non-scientist, the concept is fascinating. In an article published 40 years ago, John wrote:

Protein turnover is the sum of all the individual proteins of the body and is therefore directly analogous to the basic metabolic rate which is the sum of all oxygen uptakes of all the cells of the body and might therefore be called the rate of oxygen turnover. The concept of BMR (basal metabolic rate) has been an extremely valuable one in physiology and medicine: it seems to me that a priori, the concept of total protein turnover should prove equally valuable.

There is no doubt that his pioneering work has indeed proved to be valuable, and the methodological and conceptual advances in this area, including now the possibility of measuring the turnover of specific proteins, all bear the thumbprint of John Waterlow.

It would not be inappropriate to describe him as a fisher of men (and women), as he attracted bright people to him and to the shores of science and allowed them to flourish and satisfy their scientific curiosity with just the correct amount of supervision and guidance. His catch included scores of young Englishmen and women who came to train under him, and several returned to prominent positions in their country. But his most durable legacy is that he appreciated that no scientific establishment could continue to flourish on the basis of attracting expatriates who would naturally return to their native land. He believed with a passion that the capacity to be part of a tradition of scientific exploration was not geographically determined. His proactive approach to incorporating West Indians into the TMRU and his belief that they had the capacity to do good work and themselves breed their own scientific children ran counter to the philosophy of his English masters. The dominant view then was that scientific establishments overseas supported by Britain were temporary and would close with the return of the British head. John challenged that view, and it was partly because of his disappointment with the treatment of his West Indian staff by those who ran the Unit from Britain that he decided to leave Jamaica and negotiated the handover of the Unit to the University of the West Indies. He returned to be the Professor of Human Nutrition in the London School of Hygiene and Tropical Medicine (LSHTM), where he continued to embellish his already formidable reputation as one of the world's foremost nutritional scientists. His lasting legacy is not only a physical structure, which has expanded, but also a scientific establishment that demonstrates the validity of his thesis. Good science can come from the Caribbean. There will be difficulties consequent on the realities of physical underdevelopment, but these can be overcome.

John was the epitome of generosity. He was generous with his time, his resources and his knowledge. When confronted by one of his trainees with a proposal, his attitude was one of 'why not' rather than one of 'how'. Thus, the research in the TMRU covered almost every conceivable aspect of childhood nutrition, particularly malnutrition. Research on infant malnutrition involved studies on appropriate dietary management, growth and development, water and electrolyte metabolism, mental and psychosocial development, cardiac and renal function, micronutrients, protein, carbohydrate and fat metabolism, gastroenterology, and endocrinology. Arising from the work of the TMRU came a regimen for treating severe malnutrition, which, when adapted for use in the field, has saved and continues to save hundreds of thousands of malnourished children and adults throughout the world. In addition, it provided a home for studies on basic renal biochemistry and such local disorders as tropical spastic paralysis.

He did nothing that he would not ask others to do. This sometimes led to the culture of self-experimentation with hilarious and sometimes hair-raising results. He would infuse himself with a mixture of amino acids without adjusting the level of acidity for fear of changing its composition and end up violently ill with a swollen arm and highly inflamed veins. But it was a good experiment!

No account of John's contribution would be complete without the mention of two remarkable women. His wife Angela devoted her own life to facilitating the development of John's scientific career. She was a remarkable woman, gracious to a fault, as generous as her John, always finding time among her many charitable pursuits to grow and develop artistically. Her cartoons for the Jamaica pantomimes, her murals in the TMRU and that of the Good Samaritan at the entrance to the Medical 
School are some of the tangible remembrances of one who was more than three times a lady. Joan Stephen was John's scientific collaborator for many years, and much of the detailed analysis of many of his early experiments bears the imprint of her fine hand. She was his companion in his later years and was a perpetual source of support and encouragement.

The Caribbean owes a great debt to this remarkable ambassador, this mighty fisher of men. He was not one for memorials, and no stele of stone or steel could really ever do justice to his memory. If he ever did call for a repayment of the debt, he would wish it to be repaid in the coin of contribution by those whom he caught and by those who follow in their scientific footsteps.

George Alleyne, David Picou and Terrence Forrester University of the West Indies

As indicated earlier, after his 25 years in the Caribbean, John Waterlow organised the transfer of the TMRU from the Medical Research Council (MRC) to the University of the West Indies as an independent department in the Faculty of Medicine. It continues to flourish there today, now as an Institute, under its Director, Terrence Forrester. The chair of Human Nutrition at the LSHTM had become vacant on the death of Ben Platt in 1969, and John was appointed to this in 1970. Platt had been one of the founding fathers of post-war Human Nutrition in Britain. He was the director of the MRC Human Nutrition Unit, formed in 1944, and also held the country's first Chair of Human Nutrition on the creation of the Department of Human Nutrition at the LSHTM in 1946. After the closure of the MRC Human Nutrition Unit in 1967, its staff moved either to the LSHTM (Philip Payne, Carey Heard and Reg Stewart) or to the Department of Food and Management Science at Queen Elizabeth College, now within King's College London (Don Naismith and Derek Miller). Although John was employed in Platt's unit continuously from 1946 until the TMRU was formally established in 1954, John had spent almost all of this time working alone in the Caribbean or West Africa, having very little contact with Platt and never publishing with him, although both were members of the 1965 Joint FAO/WHO expert group on Protein Requirements. Thus, while for the LSHTM John was an obvious successor to Platt, for John it was new territory with new people.

John later remarked that as the only department of Nutrition within a school of Public Health in Europe, he saw his task at the LSHTM as building up a department that stood on four legs - metabolism; clinical nutrition; public health nutrition; nutrition policy, and he certainly achieved this. There was considerable overlap of the existing LSHTM research interests with that of John's. Thus, Platt with Carey Heard and Reg Stewart had developed descriptive animal models of protein - energy deficiency, and Philip Payne had evaluated dietary protein utilisation in animal models and had written about protein requirements. As a result, both Philip and John were members of the 1971 FAO/WHO expert consultation on Energy and Protein Requirements, which was the first truly science-based report and which controversially lowered the protein requirement. They also collaborated on a 1975 Nature paper, The Protein Gap, debunking the concept of a worldwide protein shortage that had developed in the previous decade, arguing that food supply (i.e. energy), rather than its quality, was the main global problem.

John strengthened the experimental base of the department's work with a new Clinical Nutrition and Metabolism Unit (CNMU) at the Hospital for Tropical Diseases built with Wellcome Trust funding. This housed most of Platt's team and John's own team, initially Peter Garlick, myself and briefly, Philip James. The CNMU soon developed into a hothouse of internationally recognised animal and human work on protein metabolism aimed at identifying mechanisms by which protein deposition and balance were nutritionally regulated at the level of protein synthesis and turnover. John's 1978 book Protein Turnover, written with Peter Garlick and myself, rapidly became a citation classic, and John updated this work in 2006, aged 90 years. Like the TMRU, most students and research fellows who worked at the CNMU subsequently assumed chairs and senior appointments throughout the world. With little available time for hands-on work, John nevertheless continued his ${ }^{15} \mathrm{~N}$ studies of whole-body protein turnover enabled, typically, by a largely self-assembled isotope ratio mass spectrometer. His experimental work on protein turnover was undoubtedly a major part of his election as FRS in 1982. Indeed, his pre-eminence as the international authority on protein was recognised with his appointment as chair of the 1981 FAO/WHO expert consultation on Energy and Protein Requirements. He wrote most of the subsequent 1985 report. His influence continued into the most recent $2007 \mathrm{WHO} / \mathrm{FAO} / \mathrm{UNU}$ protein report with him attending consultation meetings, 45 years after his first FAO/WHO meeting, and with his acolytes, Peter Garlick and myself, writing most of the report.

John's overriding preoccupation with infantile protein energy malnutrition meant that he maintained links with the TMRU, especially after Ann Ashworth-Hill transferred from the TMRU to the LSHTM, and in the early 1970s, he became concerned with the unsatisfactory classification systems for malnutrition in children. His inspired solution was a simplification based on resolving underweight for age into the two types of growth deficit, underweight for height (wasting) and depressed height for age (stunting), each defined as values with $Z$ scores $\leq-2$ compared with reference values. He argued that these terms describe what is observed without begging questions about the cause. They are now universally used in reports on malnutrition prevalence. This has allowed recognition that stunting is by far the most prevalent type of malnutrition globally, a very serious problem given the work by Sally Grantham-McGregor at the TMRU showing its consequences in terms of impaired mental development and other functional impairments. John's book Protein Energy Malnutrition (1992/2006), written with contributions from Andrew Tomkins, who had succeeded Philip James at the LSHTM, and Sally Grantham-McGregor, brought together John's understanding of the clinical and biomedical aspects of protein-energy malnutrition and the public health aspects of the subject in equal measure. His final publication, appearing after his death, was his reflections on stunting. 
Classification of malnutrition in adults was also problematic, and John said that he was never very impressed with the somewhat complicated ranges of desirable weight-height indices from the Metropolitan Life Insurance Tables. Instead, in 1988, when called upon to define undernutrition, he utilised precise measures of weights and heights of army recruits measured by Edholm in the late 1960s and other army data assembled by John Durnin. He argued that because this was a healthy population, the lower limit of weight $(\mathrm{kg}) /$ height $^{2}\left(\mathrm{~m}^{2}\right)$ (BMI) within the cohort would define the cut-off for undernutrition. In fact, the 5th and 95th centiles of BMI calculated from Edholm's reported values are 18.7 and $25.5 \mathrm{~kg} / \mathrm{m}^{2}$, and these became the currently accepted BMI healthy cut-off values of 18.5 and $25 \mathrm{~kg} / \mathrm{m}^{2}$.

Although protein and undernutrition remained John's primary interest, his public health interests widened. Obesity was starting to emerge as an important public health problem, and the CNMU was linked to University College Hospital (UCH) through John's honorary consultancy post and an obesity clinic that was managed by John or staff from the CNMU. In 1975, John chaired the first government committee to declare obesity a health hazard. He was also appointed as Consultant Adviser on Nutrition at the Department of Health and Social Services (DHSS), and this enabled the establishment of a clinical nutrition laboratory managed by Dr Joan Stephen to evaluate nutritional status of the elderly and other population groups sampled in national DHSS nutritional surveys. This laboratory brought both David Thurnham and Hilary Powers to the LSHTM. John was also appointed as Nutrition Adviser to the Overseas Development Administration (ODA), He recounted that because of the poor appreciation of nutrition within the ODA management, his frequent reports on what should be done about nutrition had absolutely no effect. However, the position did enable him to visit and report on projects and programmes in a number of countries: Nepal, India, Bangladesh, Thailand and Egypt.

The change from head of Research Unit to head of a university department involved several new responsibilities for John, one of which was teaching. In 1970, the LSHTM department had for some time been running a very successful postgraduate diploma course in Human Nutrition involving Joyce Doughty, T. P. Eddy and Erica Wheeler. John helped develop this into an MSc programme in 1971, broadening its base to range from nutritional metabolism to nutrition policy, and this was further strengthened when John Rivers joined the department. This increased its attraction, and students were recruited from all over the world, several of them holding senior positions in international organisations. As with the ex-research staff at the CNMU, the MSc student alumni now represent a large international influential cadre of nutritionists working at the highest level.

Another new responsibility, as head of a nutrition department, was the state of nutritional science and the role of the professional nutritionist. He argued in his 1981 Boyd Orr lecture that for both nutrition as a science and nutritionists as professionals, there was a crisis of identity. The 1980s were certainly a difficult time for nutrition in the universities. At the time of his retirement in 1982, there was an acceleration in the decline in university funding, which had started in 1974; molecular biology was capturing an increasing fraction of dwindling research funding, and the LSHTM was forced to freeze its Chair in Human Nutrition for more than a decade. John had argued that there were difficult problems of major importance that nutritionists were specially equipped by outlook and training to tackle, citing adaptive changes in energy expenditure in the undernourished and stunting as examples. He stated that nutrition occupied a 'middle place' in the chain of knowledge and endeavour between molecular biology and the social and political sciences, offering its own unique knowledge base and skill sets as well as being able to actively bring together the biological and social sciences. Most importantly, he started to identify himself as a nutritionist, which is the most valuable contribution to the discipline which any great scientist can make.

It is well known but worth recording here that John's contributions were widely recognised in his lifetime. Recognition included an honorary degree (DSc University of Reading 1984), election to the US National Academy of Sciences (1992), prizes (Bristol-Myers 1984, Rank Prize Funds 2000) and numerous named lectures. The publication of papers presented at his Festschift at the LSHTM on his 80th birthday includes authors from Turkey, Switzerland, Italy, Denmark, India, Peru, the USA, the Czech Republic as well as the UK and the Caribbean. One of them, Buford Nicols, then director of the Agricultural Research Service/United States Department of Agriculture (ARS/USDA) Children's Nutrition Research Center (CNRC) in Houston Texas, named his Metabolic Research Unit as the Waterlow Unit in Recognition of John's service as Chair of the Scientific Advisory Committee from 1978 to 1993. Vernon Young identified John's ideas and experimental approach as the stimulation for his own work on human protein and amino acid metabolism. At a Rank Prize Funds meeting in Jamaica in 1980 on Nitrogen Metabolism in Man, Denny Bier, the current director of the CNRC in Houston and an early convert to Waterlow's tracer kinetic approach with whom the CNMU collaborated, commented that this was the first time he had witnessed the transfer of leading-edge science from the third world to the USA.

John Waterlow was characterised by an extraordinary combination of physical toughness and intellectual brilliance, yet he was extraordinarily kind and generous to all who worked for him. Most importantly, he allowed us to both learn and profit from his intellect and ideas in an unrestricted way, in some cases even removing his name from publications of scientific work he had conceived, directed and largely written on the basis that it would help our careers. In my own case, it certainly did. Such behaviour is sadly all too rare in science.

His analytical objectivity was not without a blind spot, which was that dietary protein deficiency is an important aetiological factor for kwashiorkor. The flaws in this argument, repeatedly pointed out by Michael Golden, include the simple fact that the 'cure' of kwashiorkor with a low-protein diet is inconsistent with kwashiorkor reflecting protein deficiency. Thus, the phased treatment regimen for the severely malnourished child, as described in John's 1992 book, includes the feeding of modest amounts of a very-low-protein diet $3.5 \%$ 
protein energy) during the initiation of the cure phase. Indeed, John recounted to me that in the early 1960s, when, according to Ann Ashworth-Hill, the phased feeding of very diluted milk feeds was the practice at the TMRU, Reg Passmore suggested to him that it was unethical to feed such a low-protein diet. Nevertheless, John always refused to defend this inconsistency and never abandoned his convictions about the importance of dietary protein deficiency, which was of course the dominant global view in his early career. Fortunately for the severely malnourished child, the aetiology of their condition is of no consequence, and John Waterlow, ultimately a practical man, adopted the treatment regimen that worked. The implementation of these principles, further developed by John's colleagues and successors at the TMRU, especially Michael Golden, now working in emergencies and famine relief and Ann Ashworth-Hill and Alan Jackson, now joint convenors of an International Task Force on Malnutrition, is his legacy.

Joe Millward

University of Surrey

We also owe John Waterlow a debt of gratitude for the development of nutrition as a profession, particularly in the UK. His role in this was an extension of his dedication to service, a value that he shared with Boyd Orr and that suffused his whole career, in England as in Jamaica. In 1980, John dramatised the challenges facing British Nutrition, by entitling his Boyd Orr lecture 'Crisis for nutrition'. He noted that, unlike in many developing countries, British nutritionists had not defined what we were trying to do, a prerequisite to a clear career structure with defined entry qualifications. As president of the Nutrition Society from 1983 to 1986, John said that nutrition 'is to a very important extent a practical subject', and set off the debate about the development of a profession alongside of the discipline. As honorary member of the Nutrition Society, he continued to inspire the development of voluntary regulation including course accreditation for the nutrition profession. He was able to celebrate the progress that the nutrition profession has made when he, as patron of the new Association for Nutrition, spoke at its formal launch at the Royal Society in summer 2010.

Jackie Landman

University of Southampton

Sir George Alleyne University of the West Indies alleyned@paho.org 